\title{
Left in the cold? Evolutionary origin of Laternula elliptica a keystone bivalve species of Antarctic benthos
}

\author{
JOHN D. TAYLOR ${ }^{1 *}$, EMILY A. GLOVER ${ }^{1}$, ELIZABETH M. HARPER ${ }^{2}$, \\ J. ALISTAIR CRAME ${ }^{3}$, CHIHO IKEBE ${ }^{1}$ and SUZANNE T. WILLIAMS ${ }^{1}$ \\ ${ }^{1}$ Life Sciences, The Natural History Museum, London SW7 5BD, UK \\ ${ }^{2}$ Department of Earth Sciences, University of Cambridge, CB2 3EQ, UK \\ ${ }^{3}$ British Antarctic Survey, Cambridge, CB3 OET, UK
}

Running Head: RELATIONSHIPS OF LATERNULA ELLIPTICA

*Corresponding author. E-mail: j.taylor@nhm.ac.uk 


\section{ABSTRACT}

The large, burrowing bivalve Laternula elliptica is an abundant component of shallow water soft substrate communities around Antarctica but its congeners are temperate and tropical in distribution and their phylogenetic relationships are obscure. A new molecular analysis of Laternulidae species shows that there are two distinct clades; one of Exolaternula species, E. spengleri and E. liautaudi possessing a ligamental lithodesma and a larger clade of species lacking the lithodesma. Of the latter, Laternula elliptica is a sister taxon to temperate and tropical species, including the species that live around the coasts of Australia from Tasmania to Darwin. It is suggested that L. elliptica was left isolated around Antarctica following the opening of the Tasman Gateway and initiation of the Circum-Antarctic Current as Australia drifted northwards following the final breakup of Gondwana. A further scenario is that as Australia moved closer to Asia species spread into tropical habitats and more widely to the Red Sea and Japan. Exolaternula species have a likely Tethyan origin and the present day range is from the Arabian Gulf, around southern Asia and as far north as southern Russia.

ADDITIONAL KEYWORDS: phylogeny - biogeography - Laternulidae - Anomalodesmata 


\section{INTRODUCTION}

Although the precise origins of the modern Antarctic marine fauna are undoubtedly complex, there has always been a distinct impression that certain elements within it are both of considerable antiquity and endemic to the southern high-latitudes (Lipps \& Hickman, 1982; Clarke \& Crame, 1989). In all probability these taxa date back to at least the Late Cretaceous - Early Palaeogene, a time when the southern margins of the Gondwana supercontinent were still more or less intact, and polar climates were significantly warmer than those of today. Zinsmeister's (1982) extensive shallow marine Weddellian Province, stretching from southern Patagonia through western Antarctica to New Zealand and eastern Australia, was established on the basis of various endemic molluscan families, one of which, the Struthiolariidae (Littorinimorpha; Stromboidea), still occurs in the region at the present day (Beu, 2009). As our knowledge of both the fossil record and molecular phylogenetics of Antarctic marine taxa has steadily improved it is becoming appropriate to ask how certain specific elements within the fauna may have evolved. Do their roots lie in some form of ancestral Weddellian province, or were they more recent immigrants? This sort of question is particularly apposite for the very common infaunal bivalve, Laternula elliptica (Anomalodesmata; Laternulidae), as its congeners can be traced northwards through temperate South Australia into the heart of the tropical Indo-Pacific realm, and then northwards again into the temperate North-West Pacific. Is this a genus that spread either into, or out of, Antarctica, and if so, when?

Laternula elliptica (King, 1832) is a large (>100 mm) infaunal bivalve abundant in shallow water and even intertidal habitats around the Antarctic continent and sub-Antarctic islands (Fig 1 A-C). Its abundance and prominence in benthic communities, and its rank as a keystone species by Harper et al. (2012), has attracted considerable research interest with a multitude of publications investigating many aspects of its biology and ecology. A few examples include: physiology (Morley et al., 2009; 2012), biochemistry (González \& Puntarulo, 2011), reproduction (Kang et al., 2003), growth rates (Ralph \& Maxwell, 1977; Brey et al., 2011), burrowing behaviour (Peck et al., 2004), trace metals (Ahn et al., 1996), shell microstructure and mineralogy (Sato-Okoshi \& Okoshi, 2008; Nehrke et al., 2012), ice scour damage (Harper et al., 2012) and proteomics (Clark et al., 2010). 
Outside of the Southern Ocean, Laternula species range from the southern temperate zone (Tasmania) through subtropical and tropical Australia, southeastern Asia, Philippines, China and Japan as far north as Peter the Great Bay in western Russia; to the west through the northern Indian Ocean, Arabian Gulf, Red Sea and, rarely, to East Africa but are absent from oceanic islands. One species, L. liautaudi is exotic to west coast USA (Miller et al., 1999 as L. marilina; or L. gracilis Fofonoff et al., 2017) and another, L. anatina, to the eastern Mediterranean (Gofas \& Zenetos, 2003). The genus is particularly speciose around Australia from where 12 nominal species have been described or recorded.

By contrast to the research focus on L. elliptica there are relatively few studies devoted to the temperate and tropical species of Laternula and most aspects of their biology and systematics remain uninvestigated. Exceptions are the morphological and ecological studies of Laternula rostrata by Morton (1973, 1976; Adal \& Morton, 1973) and Prezant et al. (2008), the physiology of species from Singapore and south Australia (Morley et al., 2009; Lai et al., 2011) and China (Zhuang, 2005), with ecological studies on Korean and Japanese species (Kang et al., 2006; Kanaya et al., 2008).

Laternula species have thin, elongate, nacreous and granular prismatic shells, a posterior gape and the external surface is covered in short spikes (Checa \& Harper, 2010). There is a prominent umbonal slit in the shell with an internal shell buttress posterior to the hinge (Savazzi, 1990). The internal ligament is set on a chondrophore and an anterior, transverse lithodesma (a calcified ossicle within the ligament),is present in some species. Siphons are long, fused and periostracum-covered (Fig. 1), with distal tentacles and siphonal eyes (Morton, 1973; Adal \& Morton, 1973). The ventral mantle is fused, with a small pedal gape and the foot is small. Arenophilic mantle glands are present on siphons (Sartori et al., 2006) and their sand adherent secretions present on juvenile shells $<10 \mathrm{~mm}$ long (Harper unpub. obs). Laternulids live in muddy, intertidal or shallow subtidal habitats, often amongst or near mangroves (Prezant et al., 2008; Lai et al., 2011), in seagrass beds (personal observations) and frequently in habitats of fluctuating or elevated salinities.

Compared with its lower latitude congeners Laternula elliptica is larger, thicker shelled (Watson et al., 2012; Prezant et al. 2015), and lacks the spikes (spinules) on the shell surface present in all other species. Apart from L. elliptica, discrimination of Laternula species is extremely confused and misidentifications abound. There is no real agreement on the number 
of living species; the latest taxonomic account (Huber, 2010) recognised 19 species (followed in WoRMS 2017 with 20 species), previously Lamy (1934) documented 15-20 species and in the best illustrated of the $19^{\text {th }}$ century monographs Reeve (1860-63) illustrated 30 species with 24 of these described as new. The type specimens from the latter work (NHMUK) are a major resource for any taxonomic study of the genus. We agree with Huber (2010) that species depictions and distributional data in many identification guides (e.g. Lamprell \& Healy, 1998) and other publications (Morton, 1976) are wrongly assigned and have led to continuing confusion. Laternula species have been divided into two subgenera (Habe, 1977) on the basis of the presence (Exolaternula) or absence (Laternula) of a lithodesma. Nevertheless, the taxonomic or phylogenetic significance of this character has been doubted (Huber, 2010). In a broader context, molecular analyses (Harper et al., 2006: Combosch et al., 2017; Williams et al., 2017) place Laternula within the Anomalodesmata in a clade with Lyonsiidae, Clavagellidae and Pandoridae but distinct from Cochlodesma (Periplomatidae) that has a similar umbonal slit but which groups with Thraciidae and Myochamidae.

Clearly, Laternula elliptica is a prominent and ecologically important element in Antarctic benthic faunas but biogeographically isolated from the warmer water species of the genus. In this study we use a molecular analysis to investigate the phylogenetic relationships of $L$. elliptica to the lower latitude species and evaluate three possible biogeographical scenarios concerning its present isolation in polar seas.

1. Is Laternula elliptica a relict species dating from a former, broader, distributional range of the genus and warmer Antarctic conditions (for example during the Early-Middle Eocene) but now isolated by the formation of Circum-Antarctic Current and has subsequently become physiologically adapted to cold conditions? An expectation arising from this scenario might be that L. elliptica is most closely related to the temperate southern Australian species.

2. Another possibility is that Laternula species originated on Late Gondwanan shallow shores and rafted northwards with Australia into the tropics after the split from Antarctica ca 30 Myr, leaving L. elliptica isolated in the Southern Ocean. This may account for the diversity of Laternula species around Australia that range from temperate conditions around Victoria/Tasmania to tropical waters to the North. Laternula species then spread and diversified into tropical Asian shallow water environments. An expectation would be that $L$. elliptica is sister to all other species or groups with the Australian taxa. 
3. A further scenario that matches the 'out of the tropics' (OTT) model developed by Jablonski et al. (2006, 2013) is that Laternula diversified on tropical-subtropical shores and later spread southwards into Antarctica during warmer conditions, with L. elliptica as a derived species.

\section{MATERIAL AND METHODS}

\section{Molecular methods}

The DNA extraction and amplification protocols of Williams et al. (2013) were used to amplify portions of four genes from 16 specimens (Table 1). The genes amplified were the nuclear 28S rRNA gene (approximately $1640 \mathrm{bp)}$ ) and three mitochondrial genes: 12S rRNA gene (approximately $610 \mathrm{bp),} \mathrm{16S} \mathrm{rRNA} \mathrm{gene} \mathrm{(approximately} 500 \mathrm{bp)}$ ) and cytochrome $b$ (405bp). Lyonsia norwegica (Lyonsiidae) and Bryopa lata (Clavagellidae) were used as outgroups having been shown in previous analyses to be sister groups of Laternulidae (Harper et al., 2006; Combosch et al., 2017; Williams et al., 2017). Sequence reactions were performed directly on purified polymerase chain reaction (PCR) products using the BigDye Terminator v1.1 Cycle Sequencing Kit (Applied Biosystems) and run on an Applied Biosystems 3730 DNA Analyzer automated capillary sequencer. Sequences for each gene fragment were assembled and edited using Sequencher (v.5.1; Gene Codes Corporation Ann Arbor, Michigan).

Mitochondrial genes of another four taxa, Lyonsia norwegica, Bryopa lata, Laternula elliptica (Antarctica) and Laternula rostrata (Singapore, herein E. spengleri) were previously published as complete, or nearly complete, mitochondrial genomes (Williams et al. 2017) and 12S, 16S and cytB sequence were taken from these sequences (GenBank Acc. KX815957; KX815959; KX815960, KX815963). Sequences for 28S rRNA genes were obtained from the same NGS genomic data set used in Williams et al. (2017) to assemble mitochondrial genomes. Briefly, genomic DNA was sequenced on 1/5 of a flowcell on an Illumina MiSeq platform (v.2 chemistry; 2x250 paired-end). Reads were analysed and assembled using Geneious (v.8.1.8; https://www.geneious.com). The data were trimmed allowing no ambiguous base calls and removing bases from the terminal ends of reads with an error probability of 0.05 or higher (i.e. those with a greater than $5 \%$ chance of being incorrect). The trimmed reads were first assembled de novo and the resulting contigs were interrogated against the NCBI database, using BLAST (Altschul et al. 1990), in order to identify 
ribosomal gene sequences. Gene boundaries were determined by comparison with other molluscan taxa. Coverage data are available in Williams et al. (2017).

Phylogenetic datasets analysed included three individual gene datasets and a combined gene dataset including all individuals that had sequences for at least three genes. Alignment of cytB sequences was unambiguous and no stop codons were observed. Sequences of ribosomal genes were aligned in Geneious (Geneious v. 8.1.8; http://www.geneious.com) using ClustalW. Poorly aligned sites in the ribosomal gene alignments were identified using the online Gblock server using all three options for a less stringent selection (v.0.91b; Castresana, 2000, http://molevol.cmima.csic.es/castresana/Gblocks_server.html) and removed from alignments. After removal of ambiguously aligned blocks of data, a total of 2,922 bp of aligned sequence remained to be used in phylogenetic analyses for the combined gene dataset (90\% of the original 3,241positions). In individual analyses, alignment lengths after Gblocks were 444 bp of sequence from 16S rRNA (89\% of 495 bp in the original alignment), 539 bp of 12S rRNA (90\% of 597 bp in the original alignment) and 1575 bp of $28 \mathrm{~S}$ rRNA ( $88 \%$ of 1785 bp in the original alignment).

The best nucleotide substitution models were determined using jModelTest (v. X; Darriba et al. 2012) using the AIC criterion. The best nucleotides substitution models were for cytB $\mathrm{HKY}+\mathrm{I}+\mathrm{G}$ and for all three rRNA genes $\mathrm{GTR}+\mathrm{I}+\mathrm{G}$. These models were used in Bayesian phylogenies implemented in MrBayes (v. 3.2.6; Huelsenbeck \& Ronquist, 2001). The analysis ran for $10,000,000$ generations, with a sample frequency of 1,000 . The first ten percent were discarded as burn-in after checking that runs had reached stationarity.

Stationarity was determined by examining traces in TRACER (v.1.6 http://tree.bio.ed.ac.uk/software/tracer/). Convergence between the two runs was tested by examining traces using TRACER and by checking that the potential scale reduction factors produced by the 'sump' command in MrBayes were close to one (Gelman \& Rubin, 1992) and that the mean standard deviation of split frequencies approached zero.

\section{Taxonomic rationale}

Because the species taxonomy of Laternula is so confused care was taken to identify the taxa included in the molecular analyses. Type material of Laternula species was examined in NHMUK and MNHN along with images of other relevant specimens from ANSP, NHMD, MHNG and WAM. Using these, plus the taxonomic revisions of Reeve (1860), Lamy (1934) and most recently Huber (2010) and figures in regional faunas (e.g. Lamprell \& Healy, 1993; Okutani, 2000; Lutaenko \& Noseworthy, 2012) augmented by the results of our molecular 
analysis herein we have derived an outline taxonomic classification (Appendix) listing what we believe are extant species and their synonyms. Notable taxonomic changes resulting from study of type material (NHMD) are that Solen spengleri Gmelin, 1791 (herein Exolaternula spengleri Fig. $1 \mathrm{D}$ ) is an earlier name for the species variously called L. anserifera (Spengler, 1793), L. truncata (Lamarck, 1818 auct.) or L. rostrata (Sowerby, 1839). Images of newly separated valves of the holotype of Anatina liautaudi Mittre, 1844 (MNHN IM- 2000-33234) indicate that it is the earliest name (herein as Exolaternula liautaudi) for the variously named northeast Asian margin species. Also genetic data (herein) show that the Australian species variously identified as Laternula gracilis, L. marilina and L. recta are a single species, with L. gracilis (Reeve, 1860) having priority. Our present estimate is that there are 15 living species of Laternulidae; further and more comprehensive sampling will likely resolve some problem areas but may also reveal the existence of cryptic species.

Institutional abbreviations: ANSP, Academy of Natural Sciences Philadelphia at Drexel University, USA; BAS, British Antarctic Survey, Cambridge, UK; MAGNT, Museum and Gallery of Northern Territory, Australia; MHNG, Muséum d’histoire naturelle, Geneva, Switzerland; MNHN, Muséum national d’Histoire naturelle, Paris, France; NHMD, Natural History Museum of Denmark, Copenhagen; NHMUK, The Natural History Museum, London, UK; WAM, Western Australian Museum, Perth, WA.

\section{RESULTS}

All individual gene trees had similar topologies to each other and to the combined gene tree shown in Figure 2. A clear result is that the sequenced Laternulidae species split into two major groups; one comprising L. spengleri from Singapore and Philippines and L. liautaudi from Japan and southeastern Russia and a second, larger group containing all the other species including L. elliptica.

A robust topology in all gene trees is that, in the larger clade, Laternula elliptica is sister group, with maximum support ( $\mathrm{P}=1.0$ ), to all the other Laternula species from Australia, southeastern Asia and southern Japan. Amongst the temperate and tropical samples there are three well-supported sub-clades. One consists of three Laternula collected from near Esperance (southern Western Australia), Papua New Guinea and southern Japan; these are similar to Laternula anatina in shell form but are genetically different from each other and we have identified them as L. creccina, L. anatina and $L$. japonica. The cooler water 
Laternula creccina is the sister group to the two warm water species. A second sub-clade includes three samples collected at Darwin, Singapore and eastern Thailand but differ from each other in the molecular tree. The sample from Darwin is closest in shell characters to $L$. boschasina. The specimen from Singapore resembles the syntypes of L. bullata and differs from the Kungkraben Bay, Thailand example which we retain as Laternula sp. The third subclade comprises Laternula from southern and eastern Australia (Port Phillip Bay (Victoria), Burrill Lake (New South Wales) and Moreton Bay (Queensland)). Laternula from these locations have been variously named in collections as L. gracilis, L. recta and L. marilina but these have only minor genetic differences suggesting that they are conspecific, with $L$. gracilis having taxonomic priority. A species from Shark Bay, Western Australia, that we identify as L. cf. corrugata is a sister to the eastern Australian Laternula gracilis.

\section{Geological record of Laternula}

Other anomalodesmatans possessing an umbonal slit (Periplomatidae) have been confused with Laternula especially in fossils and many records of fossil Laternula can be discounted. For example, the so-called Laternula fuchsi (Hoernes, 1875) widely reported from the Miocene (Burdigalian) of eastern Europe (Harzhauser et al., 2011) is a periplomatid, as is Laternula ravni Schnetler, 2001 from the Paleocene of Denmark. Furthermore, the 'Laternula' species widely reported from the Cenozoic of far Eastern Russia are now classified as Periplomatidae (Kafanov et al., 2001).

A search of fossil literature for records of bivalves that resemble our concept of Laternula indicates that they are rare. This may be a consequence of the poor preservation potential of the thin, fragile, aragonitic shells and also the association with mangrove and organic-rich sediments from estuarine settings. Anatina burdigalensis Cossmann \& Peyrot, 1909 122-3 pl. LXIII fig 34 from the Miocene (Serravallian 13.82 -11.63 Myr) of Aquitaine Basin, France, resembles the living Exolaternula spengleri in shape (Fig. $1 \mathrm{G}$ ). Fossils resembling the living Exolaternula liautaudi have been recorded as L. limicola from the mid Miocene of central Japan (Itiogawa et al., 1981-2). Crame (1984) reported Laternula spp. from late Neogene (Pliocene?) deposits from Makran coast, Pakistan and these samples (in NHMUK) have shapes resembling living L. anatina. An earlier fossil from the Eocene Rio Turbio Formation of Patagonia (mid Lutetian - mid Priabonian 44.6 - 34 Myr - date from González Estebenet et al. (2014) described and figured as Laternula sp. by Griffin (1991: fig.10 1-2) is broadly similar to L. spengleri in shape (Fig. $1 \mathrm{H}, \mathrm{I})$. A possible Late Cretaceous 
(Campanian/Maastrichtian) Laternula sp, has been described from Argentina (Parras \& Griffin, 2013); this is more equivocal in attribution but has an umbonal slit and buttress. Further back in time some Mesozoic genera have been assigned to the Laternulidae, namely Anatimya, Cercomya, Plectomya and Platymyoidea (Keen \& Cox, 1969) but these appear morphologically distant from living Laternula.

\section{History of Laternula in Antarctica.}

Careful re-examination of both reference collections and the literature indicates that there are no bona fide Early Cenozoic representatives of Laternula from the extensive Early Cenozoic fossil record of Antarctica. The Oligocene - Miocene interval is much less complete (Beu, 2009; Beu \& Taviani, 2014). The earliest unequivocal record of the genus is that known from the Cockburn Island Formation, which forms part of a complex sequence of glacial and interglacial sediments inter-bedded with the late Neogene James Ross Island Volcanic Group (JRIVG), north-eastern Antarctic Peninsula (Smellie et al., 2013; Beu \& Taviani, 2014). Specimens from the type area of the formation, Cockburn Island (64 $\left.12^{\prime} \mathrm{S}, 56^{\circ} 50^{\prime} \mathrm{W}\right)$, were assigned to Laternula elliptica by both Soot-Ryen (1952) and Jonkers (1998a), with the only difference being that their maximum size (150mm+ in length) somewhat exceeded those of the modern form (Fig. 1 F). However, in all other respects they are very close to living $L$. elliptica and we see no need to assign them to a separate taxon. Co-occurring specimens of the large pectinid Austrochlamys anderssoni (Hennig) have been reliably dated at 4.7 Myr by ${ }^{87} \mathrm{Sr} /{ }^{86} \mathrm{Sr}$ isotopes, and this age agrees well with that of $4.7-4.9 \mathrm{Myr}$ for underlying basaltic lavas of the JRIVG $\left({ }^{40} \mathrm{Ar} /{ }^{39} \mathrm{Ar}\right.$ dating) (Smellie et al., 2013). The $4.7 \mathrm{Myr}$ age (i.e. earliest Pliocene) for the specimens of L. elliptica from Cockburn Island represents the earliest definitive fossil record of the genus from Antarctica. Within the James Ross Island group there are sparse records of Laternula from younger glacial/interglacial sediments interbedded with the JRIVG (i.e. the Hobbs Glacier Formation and its lateral equivalents). For example, Laternula sp. is noted from the southern end of Sykes Cliffs on the western side of Croft Bay (64 ${ }^{\circ} 01^{\prime}$ S, $57^{\circ} 49^{\prime} \mathrm{W}$ ) (Jonkers, 1998b), and a poorly constrained ${ }^{40} \mathrm{Ar} /{ }^{39} \mathrm{Ar}$ age from overlying lavas was resolved to be 2.38 Myr (Smellie et al., 2013). A potentially older Antarctic specimen of Laternula has been recovered from the Battye Glacier Formation, Prince Charles Mountains, East Antarctica (70 48’S, 68²0’E). Although it clearly possesses a buttressed chondrophore and nacreous inner shell layer, it is very incomplete and can only doubtfully be referred to Laternula? sp. (Stilwell et al. 2002, figs $2 \mathrm{~m}-\mathrm{n}$ ). The suggested Middle - Late Miocene age range for the Battye Glacier Formation is based on the 
associated diatom assemblage. Better preserved material is available from the Sørsdal Formation, Marine Plain, Vestfold Hills, East Antarctica (68 38’ S, 78 8’ E), and this has been identified as L. elliptica (Quilty et al. 2016). The Sørsdal Formation is dated by diatoms as Early Pliocene, 4.2 - 4.1 Myr (Quilty et al., 2016). There is an Early Pleistocene record of L. elliptica from the Scallop Hill Formation of McMurdo Sound (78 $11^{\prime}$ S, $\left.166^{\circ} 58^{\prime} \mathrm{E}\right)$ (Galasian, early Pleistocene, Speden, 1962; Beu \& Taviani, 2014), and widespread evidence for a Late Quaternary - Holocene circum-Antarctic distribution of the species (Pickard, 1985).

\section{DISCUSSION}

The results show clearly that there are two distinct phylogenetic groups of Laternula species; the clade comprising $L$. spengleri and $L$. liautaudi with both species possessing a lithodesma and the larger clade of all the other species where it is lacking in the adult. A lithodesma is present in the majority of anomalodesmatan families including Pandoridae, Lyonsiidae and Clavagellidae, the sister clades to Laternula (Harper et al., 2000; 2006). Thus its presence in some species is interpreted as a retained plesiomorphic character and its absence in the larger clade as an apomorphic state. Contrary to Savazzi (1990: 100), only three species of Laternula are known to possess a lithodesma in adult shells: L. spengleri, L. liautaudi and $L$. erythraea (the latter not molecularly sampled) and the two species form a robust clade that supports their classification in a distinct genus, Exolaternula, although other shell characters appear similar to Laternula species. Significantly, Sartori (2009) reported and illustrated lithodesmas in juvenile L. elliptica with shell lengths less than ca $12 \mathrm{~mm}$ but these become resorbed in larger shells. This ontogenetic loss of a lithodesma has also been reported in some Thraciidae species (Sartori \& Ball, 2009).

The three known Exolaternula species are distributed today along the northern Indian Ocean and Arabian Gulf (E. erythraea), through southeast Asia (E. spengleri), China, Korea and Japan as far north as Peter the Great Bay, Russia (E. liautaudi). The latter also occurs as an exotic on west coast USA (Miller et al., 1999). The distribution of E. spengleri touches the very north of Australia, with a single $19^{\text {th }} \mathrm{C}$ (NHMUK) record from Port Essington, Northern Territory. The distribution given in Lamprell \& Healy (1998) of this species (as L. rostrata) 
around southern Australia and New South Wales and followed in some ecological studies, is erroneous and based on misidentifications.

It seems likely, that Exolaternula split from the other Laternula in the early Cenozoic with the clade having a different biogeographic history. We suggest that the present day distribution of Exolaternula, restricted to the northern Indian Ocean and southern and eastern margins of Asia, reflects a Tethyan origin. The Miocene Anatina burdigalensis from southern France resembles E. spengleri in shell form and we consider it as a species of Exolaternula, the last survivor in western Tethys before the early Miocene closure of the Tethyan Seaway (Harzhauser et al., 2007). Fossils resembling the living Exolaternula liautaudi were present in Japan at least by the mid-Miocene (Itiogawa et al., 1981, 1982).

In the Laternula clade the sister position of Laternula elliptica relative to all other species suggests a separation before the diversification of the temperate and tropical species. This is consistent with the scenario that L. elliptica or its precursor was left isolated around Antarctica after the separation and northward movement of Australia with the opening of the Tasman Gateway and onset of the Antarctic Circumpolar Current ca $30 \mathrm{Myr}$ in the early Oligocene (Scher et al., 2015). This final breakup of the Gondwanan-Weddellian Province (Zinsmeister, 1979) would have disrupted larval interchange as Australia progressively moved northwards. Subsequently, as Australia moved into lower latitudes, warmer water species such as L. anatina may have spread into southeast Asia and the northern Indian Ocean while Australia retained a diversity of temperate water endemic species such as $L$. gracilis, L. creccina and L. tasmanica or their precursors. The scenario that L. elliptica originated from a southward migration as a more derived taxon (out of the tropics hypothesis (Jablonski et al., 2006, 2013)) during a period of polar amelioration can be rejected.

A single record from Pliocene of New Zealand of a fragmentary fossil, Laternula synthetica Marwick, 1948, with an estimated shell length of 120 mm (later renamed L. laterna Lamarck, 1818 by Beu, 2004) was interpreted to have arrived during a warm period. However, the long pallial sinus of this fossil precludes identification as L. laterna (a tropical species) that has a short sinus, it most closely resembles the southeastern Australian species, L. gracilis and $L$. tasmanica. 
Although it would be desirable to include more samples in the analysis our results are consistent with an Australian origin for the tropical Laternula. For example Laternula creccina from temperate southern Australia is a sister species to tropical L. anatina from Papua New Guinea and sub-tropical L. japonica from Japan. Similarly, L. cf. boschasina from Darwin, northern Australia, is sister species to two tropical species from Singapore and Thailand. Moreover, the diversity of Laternula species around Australia and their wide latitudinal spread compared with other Indo-West Pacific areas is also evidence supporting this idea.

Of the Laternula species, L. anatina (Fig. 1 E) has the broadest distribution, recorded from Kenya, Red Sea, the northern Indian Ocean, through southeastern Asia, northern Australia to Philippines, China and southern Japan. It is also present as a Lessepsian invader into the eastern Mediterranean (Gofas \& Zenetos, 2003). Nonetheless, our preliminary molecular results suggest that cryptic species may exist; for example, the frequently synonymised $L$. japonica is genetically distinct from L. anatina. Other species at lower latitudes have narrower ranges, L. navicula in the northern Indian Ocean, L. boschasina in southeast Asia and L. laterna around northern Australia.

Our phylogenetic evidence supports the idea that Laternula elliptica or its precursor was isolated around Antarctica following the split and northward movement of the Australian continent with the opening of the Tasman Gateway and initiation of the Circum-Antarctic Current. Following separation and onset of cooling conditions the species became adapted physiologically to lower temperatures (Peck et al., 2009). Laternula elliptica differs morphologically from congeners in its much larger size, very wide posterior gape, thicker shell (Watson et al., 2012) and prominent periostracum. It also lacks the exterior shell spikes characteristic of all other Laternula species and many other anomalodesmatans (Checa \& Harper, 2010). Laternula elliptica is abundant in shallow water around Antarctica particularly at depths of 10-30 m and even intertidal (Waller et al., 2017) with population densities reported up to 65/m² (Dell, 1990; Zamorano et al., 1986). The general lack of durophagous predators (decapod crustaceans and fish) in Antarctic seas (Clarke et al., 2004) could be a contributory factor in its success. By comparison the lower latitude species of Laternula tend to occupy peripheral marine habitats where predation pressure is likely reduced, such as mangrove fringes (Morton, 1973; Prezant et al., 2008), estuaries with fluctuating salinities (Kanaya et al., 2008; Kang et al., 2006), or locations with elevated salinities such as Shark 
Bay, Western Australia (Logan \& Cebulski, 1970) or the Arabian Gulf (Sheppard et al., 2010).

Corroboration of the biogeographical scenarios with a fossil record would be desirable but as already noted the fossil record of Laternula is poor. The only Southern Hemisphere Early Cenozoic occurrence, Laternula sp. from the Eocene Rio Turbio Formation, Santa Cruz Province, Argentina, is part of a still imperfectly known molluscan fauna that does show at least some resemblance to that known from the La Meseta Formation of Seymour Island, north-eastern Antarctic Peninsula (Griffin, 1991). Palaeogeographic reconstructions for the Eocene connection between Tierra del Fuego and the northern tip of the Antarctic Peninsula are complex, but some of the most recent ones, based on new marine geophysical data, place the Rio Turbio basin at a significantly higher palaeolatitude than its present day position of

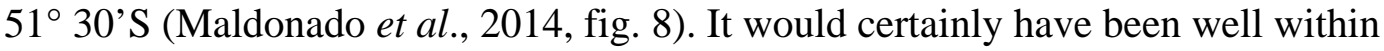
Zinsmeister's (1979, 1982, 1984) Weddellian Province and Laternula sp. may represent part of the ancestral lineage of L. elliptica. The Rio Turbio Formation does appear to contain a series of distinct sedimentary facies that are missing in the La Meseta Formation, and the two units almost certainly represent slightly different types of shallow marine environment (Griffin, 1991).

As a result of recent taxonomic and stratigraphic studies it has been determined that approximately one-third of the 147 gastropod and bivalve species known from the Middle Eocene section of the La Meseta Formation can now be assigned to modern genera (Beu, 2009; Crame et al., 2014). This means that, for at least one key part of the modern Antarctic marine fauna, it was beginning to take shape some $10-15$ Myr before the onset of significant global cooling at the Eocene - Oligocene boundary (Zachos et al., 2008). Molecular phylogenetic evidence suggests that the amphipod genus Epimeria, which today forms a species flock in the Southern Ocean, diversified initially in the Middle or Late Eocene (Verheye et al., 2017), and the split between the Antarctic/subantarctic limpet Nacella and its temperate to tropical sister taxon Cellana occurred at 32 Ma (GonzálezWevar et al., 2017). There is even a combination of molecular phylogenetic and biogeographic evidence from the Antarctic terrestrial realm to suggest that a range of taxa had similar Early Cenozoic roots, and have survived to the present day using various types of refugia (Convey et al., 2008). All of this evidence suggests that the Antarctic biota is of considerable ancestry and has been able to adapt to progressive global cooling over a period of tens of millions of years. Laternula had Eocene or even earlier roots in the Antarctic 
region and was then able to adapt to both the cooling of Antarctica and the warming of the Australian continent as it moved progressively northwards.

Despite the present day diversity and abundance of Laternula species around Australia the fossil record from there is lacking, with no mention of the genus in Darragh's (1985) analysis of the Cenozoic molluscan faunas of southeastern Australia. However, the stratigraphic record is very patchy and suitable facies are not preserved and, coupled with the preferred marginal marine habitats and fragile shells, may account for the lack of Laternula fossils. However, Pufahl et al. (2004) report Laternula sp. from Pliocene estuarine deposits in the Murray Basin, South Australia. The fossils are preserved as casts and molds with aragonitic shells dissolved away and identifications were made in the field (N. James personal communication). If confirmed, these are the only Laternula fossils recorded from Australia.

In summary, our molecular results revealed two distinct groups of living Laternulidae; Exolaternula species possessing a lithodesma and a distribution largely around the northern Indian Ocean and the southern margin of the Asian continent. The Exolaternula clade likely had a Tethyan origin with connections to the western Tethys in the early Miocene but later severed by the closure of the Tethyan Seaway. The more numerous Laternula species lack a lithodesma in the adult, with the Antarctic L. elliptica as a sister taxon to all other species from Australia and central Indo-West Pacific. The Laternula clade likely originated on the Late Gondwanan southern Australia/Antarctica continent, leaving L. elliptica isolated around Antarctica after Australia split and drifted northwards opening the Southern Ocean.

Temperate and tropical species exist around Australia but we suggest that the tropical species spread and diversified into coastal Asia from the mid-Miocene onwards after the closer approach of Australia.

\section{ACKNOWLEGEMENTS}

For generously providing samples we are grateful to Ruytoro Goto (University of Kyoto), Barbara Buge (MNHN), Konstatin Lutaenko (Russian Academy of Sciences, Vladivostok), Koh Siang Tan (National U. of Singapore), Piotr Kuklinski (Institute of Oceanology, Polish Academy of Sciences) and Simon Morley (BAS). Dawn Woods, George Mulvaney and Michael Mulvaney helped collect samples at Burrill Lake, New South Wales.

Grateful thanks are due to Tom Schiotte (NHMD) for images of the Mya anserifera holotype, Emmanuel Tardy (MHNG) for images of the lectotype of Anatina laterna, Virginie Héros 
(MNHN) for arranging opening of valves and images of the holotype of Laternula liautaudi, Konstantin Lutaenko and Elena Chaban (Zoological Museum, St Petersburg) for searching for the type of L. japonica and Lisa Kirkendale (WAM), Richard Willan (MAGNT) for images of shells in their collections. David Cothran generously allowed reproduction of his images of living L. elliptica. Tom Darragh (Museum Victoria) advised on Australian fossil faunas, Pierre Lozouet (MNHN) confirmed dating of fossils and Takuma Haga (NMNS, Tokyo) provided information and literature concerning Japanese living and fossil species. We thank Lisa Smith (NHMUK) for help with molecular analyses and Adrian Glover (NHMUK) who facilitated the process. JAC acknowledges financial support from NERC, including NE/I00582X/1. The work of the late Solene Morris former curator of bivalves at NHMUK is acknowledged for careful curation of the Laternula type specimens. We thank Alan Beu and another reviewer for thoughtful comments and suggestions.

\section{REFERENCES}

Adal MN, Morton B. 1973. The fine structure of the pallial eyes of Laternula truncata (Bivalvia: Anomalodesmata: Pandoracea). Journal of Zoology 170: 533-556.

Ahn IY, Lee SH, Kim KT, Shim JE, Kim DY. 1996. Baseline heavy metal concentrations in the Antarctic clam, Laternula elliptica in Maxwell Bay, King George Island, Antarctica. Marine Pollution Bulletin 32: 592-598.

Altschul SF, Gish W, Miller W, Myers EW, Lipman DJ. 1990. Basic local alignment search tool. Journal of Molecular Biology 215: 403-410.

Beu AG. 2009. Before the ice: Biogeography of Antarctic Paleogene molluscan faunas. Palaeogeography, Palaeoclimatology, Palaeoecology 284: 191-226.

Beu AG, Taviani M. 2014. Early Miocene Mollusca from McMurdo Sound, Antarctica (ANDRILL 2A drill core), with a review of Antarctic Oligocene and Neogene Pectinidae (Bivalvia). Palaeontology 57: 299-342.

Beu AG. 2004 Marine Mollusca of oxygen isotope stages of the last 2 million years in New Zealand. Part 1: Revised generic positions and recognition of warm - water and cool water migrants. Journal of the Royal Society of New Zealand 34: 111-260.

Brey T, Voigt M, Jenkins K, Ahn I-Y. 2011. The bivalve Laternula elliptica at King George Island - a biological recorder of climate forcing in the West Antarctic Peninsula region. Journal of Marine Systems 88: 542-552.

Castresana J. 2000. Selection of conserved blocks from multiple alignments for their use in 
phylogenetic analysis. Molecular Biology and Evolution 17: 540-552.

Checa AG, Harper EM. 2010. Spikey bivalves: intraperiostracal crystal growth in anomalodesmatans. Biological Bulletin 219: 231-248.

Chemnitz JH. 1782. Neues systematiches Conchylien-Cabinet. Volume 6 1-375 pls1-36. Raspe, Nürnberg.

\section{Clark MS, Thorne MAS, Viera FA, Cardosa JCR, Power DM, Peck LS. 2010.}

Insights into shell deposition in the Antarctic bivalve Laternula elliptica: gene discovery in the mantle transcriptome using 454 pyrosequencing. BMC Genomics 11: 362. DOI: 10.1186/1471-2164-11-362

Clarke A, Crame JA. 1989. The origin of the Southern Ocean marine fauna. In: Crame, J.A. ed. Origins and evolution of the Antarctic biota. Geological Society London, Special Publications, 47, 253-268.

Clarke A, Aronson RB, Crame JA, Gili J-M, Blake DB. 2004. Evolution and diversity of the benthic fauna of the Southern Ocean continental shelf. Antarctic Science 16: 559-568.

Coan EV, Petit RE, Zelaya DG. 2011. Authorship and date of a key South American paper by Phillip P. King (1832). The Nautilus 125: 86-88.

Combosch DJ, Collins TM, Glover EA, Graf DL, Harper EM, Healy JM, Kawauchi GY, Lemer L, McIntyre E, Strong EE, Taylor JD, Zardus JD, Mikkelsen PM, Giribet G, Bieler R. 2017. A family-level Tree of Life for bivalves based on a Sanger-sequencing approach. Molecular Phylogenetics and Evolution 107: 191-208

Convey P, Gibson JAE, Hillenbrand C.D, Hodgson DA, Pugh PJA, Smellie JL, Stevens, MI. 2008. Antarctic terrestrial life - challenging the history of the frozen continent? Biological Reviews 83: 103-117.

Cossmann M, Peyrot A. 1909. Conchologie néogénique de L’Aquitaine. Actes de la Société Linnéenne de Bordeaux. 63(2): 73-144.

Crame JA. 1984. Neogene and Quaternary Mollusca from the Makran Coast, Pakistan. In: Haq BU, Milliman JD eds. Marine geology and oceanography of Arabian Sea and coastal Pakistan. New York: Van Nostrand Reinhold, 45-61.

Crame JA, Beu AG, Ineson JR, Francis JE, Whittle RJ, Bowman, VC. 2014. The Early origin of the Antarctic marine fauna and its evolutionary implications. PLOS ONE 9(12): e114743. doi:10. 1371/journal.pone.011474

Darragh TA. 1985. Molluscan biogeography and biostratigraphy of the Tertiary of 
southeastern Australia, Alcheringa: An Australasian Journal of Palaeontology 9: 83-116.

Darriba D, Taboada GL, Doallo R, Posada D. 2012. jModelTest 2: more models, new heuristics and parallel computing. Nature Methods 9: 772-772.

Dell RK. 1990. Antarctic Mollusca with special reference to the fauna of the Ross Sea. Bulletin of the Royal Society of New Zealand 27: 1-311.

Feulner GR, Hornby RJ. 2006. Intertidal molluscs in UAE lagoons. Tribulus 16: 17-23

Fofonoff PW, Ruiz GM, Steves B, Simkanin C, Carlton JT. 2017. National Exotic Marine and Estuarine Species Information System. http://invasions.si.edu/nemesis/. Access Date: 31-Jul -2017.

Gelman A, Rubin DB. 1992. Inference from iterative simulation using multiple sequences (with discussion). Statistical Science 7: 457-511.

Gmelin JF. 1792. Caroli a Linné systema naturae per regna tria naturae $13^{\text {th }}$ edition volume 1, part 6 Vermes, pp. 3021-3910.

Gofas S, Zenetos A. 2003. Exotic molluscs in the Mediterranean Basin: current status and perspectives. Oceanography and Marine Biology: an Annual Review 41, 237-277.

González, PM, Puntarulo S. 2011. Iron and nitrosative metabolism in the Antarctic mollusc Laternula elliptica. Comparative Biochemistry and Physiology, Part C 153: 243-250.

González Estebenet MS, Guerstein GR, Rodriguez Raising ME. 2014. Middle Eocene dinoflagellate cysts from Santa Cruz Province, Argentina: biostratigraphy and paleoenvironment. Review of Palaeobotany and Palynology 211: 55-65.

González-Wevar CA, Hüne M, Segovia NI, Nakano T, Spencer HG, Chown SL, Saucède T, Johnstone G, Mansilla A, Poulin E. 2017. Following the Antarctic Circumpolar Current: patterns and processes in the biogeography of the limpet Nacella (Mollusca: Patellogastropoda) across the Southern Ocean. Journal of Biogeography 44: 861-874.

Grabau AW, King SG. 1928. Shells of Petaiho. Handbook No. 2. Peking, Peking Society of Natural History.

Griffin M. 1991. Eocene bivalves from the Rio Turbio formation, southwestern Patagonia (Argentina), Journal of Paleontology 65: 119-146.

Habe T. 1952. Astartidae, Crassatellidae, Mesodesmatidae and Laternulidae in Japan. In: Kuroda T, ed. Illustrated Catalogue of Japanese Shells 22: 161-172.

Habe T. 1977. Systematics of Mollusca in Japan. Bivalvia and Scaphopoda. Tokyo: Hokuryan. 
Harper EM, Hide EA, Morton B. 2000. Relationships between the extant Anomalodesmata: a cladistic test. In: Harper EM, Taylor JD, Crame JA, eds The Evolutionary Biology of the Bivalvia. Geological Society of London Special Publications 77: 129-143.

Harper EM, Dreyer H, Steiner G. 2006. Reconstructing the Anomalodesmata (Mollusca: Bivalvia): morphology and molecules. Zoological Journal of the Linnean Society 148: 395-420.

Harper EM, Clark MS, Hoffman JI, Philipp EER, Peck LS, Morley, SA. 2012. Iceberg scour and shell damage in the Antarctic bivalve Laternula elliptica. PLOS ONE 7(9): e46341.

Harzhauser M, Kroh A, Mandic O, Piller WE, Gohlich U, Resuter M, Berning B. 2007. Biogeographic responses to geodynamics: a key study all around the Oligo-Miocene Tethyan Seaway, Zoologischer Anzeiger 246: 241-256.

Harzhauser M, Mandic O, Schlögl J. 2011. A late Burdigalian bathyal mollusc fauna from the Vienna Basin (Slovakia). Geologica Carpathica 62: 211-231.

Huelsenbeck JP, Ronquist F. 2001. MRBAYES: Bayesian inference of phylogenetic trees. Bioinformatics 17: 754-755.

Hoernes R. 1875. Die Fauna des Schliers von Ottnang. Jahrbuch der Kaiserlich Königlichen Geologischen Reichsanstalt 25: 333-400.

Huber M. 2010. Compendium of Bivalves. A full-color guide to 3,300 of the World's marine bivalves: A Status on Bivalvia After 250 years of research. Hackenheim, Germany: ConchBooks.

Itoigawa J, Shibata H, Nishima H, Okumura Y. 1981 Miocene fossils of the Mizunami group central Japan. 2. Molluscs. Monograph of the Mizunami Fossil Museum 3A: 1-53, 52 plates (in Japanese)

Itoigawa J, Shibata H, Nishima H, Okumura Y. 1982. Miocene fossils of the Mizunami group, central Japan. 2. Molluscs (continued). Monograph of the Mizunami Fossil Museum 3B: 1-330 (in Japanese)

Jablonski D, Roy K, Valentine, JW. 2006. Out of the tropics: evolutionary dynamics of the latitudinal diversity gradient. Science 314: 102-106.

Jablonski D, Belanger CL, Berke SK, Huang S, Krug AZ, Roy K, Tomasovych A, 
Valentine JW. 2013. Out of the tropics, but how? fossils, bridge species, and thermal ranges in the dynamics of the marine latitudinal diversity gradient. Proceedings of the National Academy of Sciences of the USA 110: 10487-10494.

Jonkers HA. 1998a. The Cockburn Island Formation; Late Pliocene interglacial sedimentation in the James Ross Basin, northern Antarctic Peninsula. Newsletters in Stratigraphy 36: 63-76.

Jonkers HA. 1998b. Stratigraphy of Antarctic late Cenozoic pectinid-bearing deposits. Antarctic Science 10: 161-170.

Kafanov AI, Ogasawara K, Marincovich L. 2001. Checklist and bibliography of the Cenozoic marine Bivalvia (Mollusca) of Northeastern Asia (Russian Far East), 1968-1999. Bulletin of the Mizunami Fossil Museum 28: 1-138.

Kanaya G, Takagi S, Kikuchi E. 2008. Spatial dietary variations in Laternula marilina (Bivalva) and Hediste spp. (Polychaeta) along environmental gradients in two brackish lagoons. Marine Ecology Progress Series 359: 133-144.

Kang Chang-Keun, Lee Yong-Woo, Choy Eun Jung, Shin Jae-Ki, Seo In-Soo, Hong Jae-Sang 2006. Microphytobenthos seasonality determines growth and reproduction in intertidal bivalves. Marine Ecology Progress Series 315: 113-127.

Kang Do-Hyung, Ahn In-Young, Choi Kwang-Sik. 2003. Quantitative assessment of reproductive condition of the Antarctic clam, Laternula elliptica (King \& Broderip), using image analysis. Invertebrate Reproduction \& Development 44: 71-78.

Keen, M, Cox LR. 1969. Family Laternulidae. In: Moore RC. ed. Treatise on Invertebrate Paleontology, Part N, Mollusca 6, Bivalvia, (2). Boulder, Geological Society of America and Lawrence, University of Kansas Press, N491-N518.

King PP. 1832. Description of Cirrhipeda, Conchifera and Mollusca, in a collection formed by the officers of H. M.S. Adventure and Beagle employed between the years 1826 and 1830 in surveying the southern coasts of South America, including the Straits of Magalhaens and the coast of Tierra del Fuego [“assisted by W. J. Broderip”]. Zoological Journal 5(19): 332-349.

Lai CH, Morley SA, Tan KS, Peck LS. 2011. Thermal niche separation in two sympatric tropical intertidal Laternula (Bivalvia: Anomalodesmata). Journal of Experimental Marine Biology and Ecology 405: 68-72. 
Lamarck J B P A. de 1818. Histoire naturelle des Animaux sans vertébres 5. Paris, Verdière, Deterville et chez d'auteur, 612 p.

Lamprell K, Healy J. 1998. Bivalves of Australia volume 2. Leiden: Backhuys Publishers. Lamy E. 1934. Revision des Anatina vivants du Museum National d'Histoire Naturelle de Paris. Journal de Conchyliologie 78: 145-168.

Linnaeus C. 1758. Systema Naturae per Regna Tria Naturae, Secundum Classes, Ordines, genera, Species, cum Characteribus, Differentiis, Synonymis, Locis. Tomus 1, $10^{\text {th }}$ ed. L. Salvii, Stockholm, Sweden. 824 pp.

Lipps JH, Hickman CS. 1982. Origin, age, and evolution of Antarctic and deep-sea faunas. In: Ernst, W.G. \& Morin, J.G. (eds) The environment of the deep sea. Rubey Volume II. Englewood Cliffs, N.J., Prentice-Hall Inc.,325-356.

Lischke CE, 1872. Diagnosen neuer Meeres-Conchylien vin Japan. Malakozoologisches Blätter 19: 100-109.

Lischke CE, 1874. Japanische Meeres-Conchylien. EinBeitrag zur Kenntnis der Mollusken Japans, mit besonderer Rücksicht auf die Geographische Verbreitung derselben. Volume 3: 1-123, pls 1-9. Theodor Fischer, Cassel.

Logan BW, Cebulski DE. 1970. Sedimentary environments of Shark Bay, Western Australia. American Association of Petroleum Geologists Memoir 13: 1-37.

Lutaenko KA, Noseworthy RG. 2012. Catalogue of the living Bivalvia of the continental coast of the Sea of Japan (East Sea). Vladivostok: Dalnauka.

Maldonado A, Bohoyo F, Galindo-Zaldivar FJ, Hernandez-Molina F J, Lobo F J, Lodolo E, Martos YM, Perez LF, Schreider AA, Somoza L. 2014. A model of oceanic development by ridge jumping: Opening of the Scotia Sea. Global and Planetary Change 123: $152-173$.

Marwick J. 1948. Lower Pliocene Mollusca from Otahuhu, Auckland. New Zealand Geological Survey Paleontological Bulletin 16, 38 pp.

Miller TW, Coan EV, Chapman JW. 1999. Rediscovery of the introduced, non-indigenous bivalve Laternula marilina (Reeve, 1860) in the northeastern Pacific. The Veliger 42: 282284.

Mittre H. 1844. Mémoire sur le genre Anatina. In: Guérin-Méneville, F.E. ed. Magasin de 
Zoologie, d'Anatomie Comparée et de Palaeontologie: 1-18, pls 102-104.

Morley SA, Tan KS, Day RW, Martin SM, Pörtner HO, Peck LS. 2009. Thermal

dependency of burrowing in three species within the bivalve genus Laternula: a latitudinal comparison. Marine Biology 156: 1977-1984.

Morley SA, Hirse T, Thorne MAS, Pörtner'HO, Peck LS. 2012. Physiological plasticity, long term resistance or acclimation to temperature, in the Antarctic bivalve, Laternula elliptica. Comparative Biochemistry and Physiology Part A: Molecular \& Integrative Physiology 162: 16-21.

Morris S, Morris N. 1993. New shells from the UAE's East Coast. Tribulus 3: 5-8, 18-19.

Morton B. 1973. The biology and functional morphology of Laternula rostrata (Lamarck, 1818) (Bivalvia: Anomalodesmata: Pandoracea). Biological Bulletin 145: 509-531.

Morton, B. 1976. The structure, mode of operation and variation in form of the shell of the Laternulidae (Bivalvia: Anomalodesmata: Pandoracea). Journal of Molluscan Studies 42: 261-278.

Nehrke G, Poigner H, Wilhelms-Dick D, Brey T, Abele D. 2012. Coexistence of three calcium carbonate polymorphs in the shell of the Antarctic clam Laternula elliptica, Geochemistry Geophysics Geosystems 13: Q05014, doi:10.1029/2011GC003996.

Okutani T. 2000. Marine mollusks in Japan. Tokyo: Tokai University Press,

Oliver PG. 1995. Bivalvia. In: Dance SP, ed. Seashells of Eastern Arabia. Dubai: Motivate Publishing, 194-281.

Parras A, Griffin M. 2013. Late Cretaceous (Campanian/Maastrichtian) freshwater to restricted marine mollusc fauna from the Loncoche Formation, Neuquén Basin, westcentral Argentina. Cretaceous Research 40: 190-206.

Peck LS, Clark MS, Morley SA, Massey A, Rossetti H. 2009. Animal temperature limits and ecological relevance: effects of size, activity and rates of change. Functional Ecology 23: 248-256.

Philippi RA. 1844. Descriptiones testaceorum quorundam novorum, maxime chinensium. Zeitschrift für Malakozoologie 1: 161-167.

Philipp EE, Husmann G, Abele D. 2011. The impact of sediment deposition and iceberg scour on the Antarctic soft shell clam Laternula elliptica at King George Island, Antarctica. Antarctic Science 23:127-138

Pickard J. 1985. The Holocene fossil marine macrofauna of the Vestfold Hills, East Antarctica. Boreas 14:189-202.

Pilsbry HA. 1895. Catalogue of the marine mollusks of Japan with descriptions of new 
species and notes on others collected by Frederick Stearns. F. Stearns, Detroit. 196 pp.

Pilsbry HA. 1901. New Japanese marine, land and fresh-water Mollusca. Proceedings of the Academy of Natural Sciences of Philadelphia. 53: 385-408.

Preston HB. 1905 Descriptions of new species of marine shells from Ceylon. Journal of Malacology 12: 1-8.

Preston HB. 1914. Mollusca from Chilka Lake on the east coast of India. Records of the Indian Museum 10: 297-310.

Preston HB. 1915. A further report on Mollusca from Chilka Lake on the east coast of India. Records of the Indian Museum 11: 289-310.

\section{Prezant RS, Sutcharit C, Chalermwat K, Kakhai N, T. Duangdee T,}

Dumrongrojwattana P. 2008. Population study of Laternula rostrata (Bivalvia:

Anomalodesmata: Laternulidae) in the mangrove sand flat of Kunkrabaen Bay, Thailand, with notes on Laternula anatina. Raffles Bulletin of Zoology Supplement 18: 57-73.

Prezant RS, Shell RM, Laying Wu. 2015. Comparative shell microstructure of two species of tropical laternulid bivalves from Kungkrabaen Bay, Thailand with after-thoughts on laternulid taxonomy. American Malacological Bulletin 33: 1-12.

Pufahl PK, James NP, Bone Y, Lukasik JJ. 2004. Pliocene sedimentation in a shallow, cool-water, estuarine gulf, Murray Basin, South Australia. Sedimentology 51: 997-1027.

Quilty PG, Darragh TA, Gallagher SJ, Harding LA. 2016. Pliocene Mollusca (Bivalvia, Gastropoda) from the Sørsdal Formation, Marine Plain, Vestfold Hills, East Antarctica: taxonomy and implications for Antarctic Pliocene palaeoenvironments. Alcheringa 40: 556-582.

Ralph R, Maxwell JGH. 1977. Growth of two Antarctic Lamellibranchs - Adamussium colbecki and Laternula elliptica. Marine Biology 42: 171-175.

Reeve LA. 1860-1863. Monograph of the genus Anatina. Conchologica Iconica volume 14, London: Reeve, Benham \& Reeve.

Röding PF. 1798. Museum Boltenianum, pars secunda continens conchlia, sive Testacea univalvia, bivalvia et multivalvia. Hamburg, JC Trapii,

Rumpf [Rumphius] GE. 1705. D'Amboinsche Rariteitkamer, behelzende eene beschryvinge van allerhande zoo weeke als harde schaalvisschen, te weeten raare krabben, kreeften, en diergelyke zeedieren, als mede allerhande hoorntjes en schulpen, die men in d'Amboinsche zee vindt: daar beneven zommige mineraalen, gesteenten, en soorten van aarde, die in d'Amboinsche, en zom- mige omleggende eilanden gevonden worden. Amsterdam, 1-340 + 1-43, 60 pls. 
Sartori AF. 2009. Comparative morphology and phylogeny of anomalodesmatan bivalves. $\mathrm{PhD}$ thesis, University of Cambridge.

Sartori AF, Ball AD. 2009. Morphology and postlarval development of the ligament of Thracia phaseolina (Bivalvia: Thraciidae), with a discussion of model choice in allometric studies. Journa of Molluscan Studies 75: 295-304.

Sartori AF, Passos FD, Domaneschi O. 2006. Arenophilic mantle glands in the Laternulidae (Bivalvia: Anomalodesmata) and their evolutionary significance. Acta Zoologica 87: 265-272.

Sato-Okoshi W, Okoshi K. 2008. Characteristics of shell microstructure and growth analysis of the Antarctic bivalve Laternula elliptica from Lutzow-Holm Bay, Antarctica. Polar Biology 31: 131-138.

Savazzi E. 1990. Shell biomechanics in the bivalve Laternula. Lethaia 23: 93-101.

Scher HD, Whittaker JM, Williams SE, Latimer JC, Kordesch WEC. Delaney ML. 2015. Onset of Antarctic Circumpolar current 30 million years ago as Tasmanian Gateway aligned with westerlies. Nature 523: 580-583.

Schnetler KI. 2001. The Selandian (Paleocene) mollusc fauna from Copenhagen, Denmark: the Poul Harder 1920 collection. Geology of Denmark Survey Bulletin 3785 pp.

\section{Sheppard C, Al-Husiani M, Al-Jamali F, Al-Yamani F, Baldwin R, Bishop J, et al.,} 2010. The Gulf: a young sea in decline. Marine Pollution Bulletin 60: 3-38.

Smellie JL, Johnson JS, Nelson AE. 2013. Geological map of James Ross Island. 1. James Ross Island Volcanic Group (1:125,000 scale). BAS GEOMAP 2 Series, Sheet 5, British Antarctic Survey, Cambridge, UK.

Soot-Ryen T. 1952. Laternula elliptica (King \& Broderip, 1831) from the Pecten Conglomerate, Cockburn Island. Arkiv fur Zoologi 4: 163-164.

Sowerby GB. II. 1839. A conchological manual. GB Sowerby, London 1-130, 24 pls

Speden IG. 1962. Fossiliferous Quaternary marine deposits in the McMurdo Sound region, Antarctica. New Zealand Journal of Geology and Geophysics 5: 746-777.

Spengler L. 1793. Beskrivelse over et nyt Slagt a£ de toskallede Konkylier, forhen a $£$ mig kaldet Chaena saa og over det Linneiske Slagt Mya, hvilket noiere bestemmes, og inddeles i tvende Slagter. 
Skrivter af Naturhistorie Selskabet, 3 (1): 16-5l.

Stilwell JD, Harwood DM, Whitehead JM. 2002. Mid-Tertiary macroinvertebrate-rich clasts from the Battye Glacier Formation, Prince Charles Mountains, East Antarctica. Antarctic Science 14: 69-73.

Verheye ML, Backeljau T, d'Udekem d'Acoz C. 2017. Locked in the icehouse: evolution of an endemic Epimeria (Amphipoda, Crustacea) species flock on the Antarctic shelf. Molecular Phylogenetics and Evolution 114: 14-33.

Waller CL, Overall A, Fitzcharles EM, Griffiths H. 2017. First report of Laternula elliptica in the Antarctic intertidal zone. Polar Biology 40: 227-230.

Watson SA, Peck LS, Tyler PA, Southgate PC, Tan KS, Day RW, Morley SA. 2012. Marine invertebrate skeleton size varies with latitude, temperature and carbonate saturation: Implications for global change and ocean acidification. Global Change Biology 18: 3026-3038.

Williams ST, Smith LM, Herbert DG, Marshall BA, Warén A, Kiel S, Dyal P, Linse K, Vilvens C, Kano Y. 2013. Cenozoic climate change and diversification on the continental shelf and slope: evolution of gastropod diversity in the family Solariellidae (Trochoidea). Ecology and Evolution 3: 887 - 917. doi: 10.1002/ece3.513

Williams ST, Foster PG, Hughes C, Harper EM, Taylor JD, Littlewood DTJ, Dyal P, Hopkins KP, Briscoe AG. 2017. Curious bivalves: Systematic utility and unusual properties of anomalodesmatan mitochondrial genomes. Molecular Phylogenetics and Evolution 110: 60-72.

WoRMS (world register of marine species). 2017. http://www.marinespecies.org/index.php (Accessed June 2017).

Zachos JC, Dickens GR, Zeebe RE. 2008. An early Cenozoic perspective on greenhouse warming and carbon-cycle dynamics. Nature 451: 279-283.

Zamorano JH, Duarte WE, Moreno CA. 1986. Predation upon Laternula elliptica (Bivalvia, Anatinidae) - a field manipulation in South-Bay, Antarctica. Polar Biology 6: 139-143.

Zhuang Q, Cai Y. 1982. Studies on the Laternulidae off the Chinese coast. Oceanologia et Limnologia Sinica 13: 553-561.

Zhuang S. 2005. Influence of salinity, diurnal rhythm and daylength on feeding in Laternula marilina Reeve. Aquaculture Research 36: 130-136.

Zinsmeister WJ. 1979. Biogeographic significance of the late Mesozoic and early 
Tertiary molluscan faunas of Seymour Island (Antarctic Peninsula) to the final breakup of Gondwanaland. In: Gray J, Boucot AJ, eds, Historical Biogeography, Plate Tectonics and the Changing Environment. Corvallis: Oregon State University Press, 349-355

Zinsmeister WJ. 1982. Late Cretaceous - Early Tertiary molluscan biogeography of the southern circum-Pacific. Journal of Paleontology 56: 84-102.

Zinsmeister WJ. 1984. Late Eocene bivalves (Mollusca) from the La Meseta Formation, collected during the 1974-1975 joint Argentine-American expedition to Seymour Island, Antarctic Peninsula. Journal of Paleontology 58: 1497-1527. 


\section{FIGURE LEGENDS}

Figure 1. Laternula elliptica, type species of Exolaternula and Laternula, and fossil Laternulidae. A. Laternula elliptica (King, 1832) James Ross Island, Antarctica (NHMUK), L= $69 \mathrm{~mm}$; B, C. Laternula elliptica, in life position with fused inhalant an exhalant siphons Images by David Cothran/Lindblad Expeditions, All Rights Reserved. D. Exolaternula spengleri (Gmelin, 1791) (senior synonym of A. truncata, A. rostrata) Port Essington, Australia (NHMUK), L = 78.4 mm; E. Laternula anatina (Linnaeus, 1758), Moluccas (NHMUK), L= 55.2 mm. F. Laternula elliptica, Early Pliocene, Cockburn Island Formation, Cockburn Island, north-eastern Antarctic Peninsula. (BAS DJ. 351.21), L= 138 mm. G. L. burdigalensis (Cossmann \& Peyrot, 1909) Miocene, Salles, France, L= 80 mm (from Cossmann \& Peyrot, 1909). H. I. Laternula. sp., Eocene, Rio Turbio Formation, Patagonia, Argentina, L = 50 mm, from Griffin (1991) with permission Journal of Paleontology.

Figure 2. Combined gene tree for Laternulidae based on sequences from four genes (28S rRNA, 12S, 16S and cyt b) using Bayesian inference as implemented by MrBayes. Support values are posterior probabilities (PP). Images are of sequenced specimens or proxies - not to scale. Colour code on localities denotes: tropical (red), temperate (green), Antarctic(blue) Locality codes used on tree: BL - Burrill Lake, New South Wales, Australia; DAR - Darwin, Australia; ESP - Esperance, Western Australia; HJ - Higata-Jima Is, Japan; GE - Geelong, Victoria, Australia; KK - Kungkraben Bay, Thailand; KS - Kojima-Shinden, Japan; LP Luzon, Philippines; MB - Moreton Bay, Queensland, Australia; OB- Olga Bay, eastern Russia; PNG - Papua New Guinea; RO - Rothera, Adelaide Island, Antarctica; SB - Shark Bay, Western Australia; SIN - Singapore; SS - South Shetland Isles.

Figure 3. Distributional ranges of Exolaternula and Laternula species in the Indo-West Pacific and Southern Oceans. Robinson projection. Red - Exolaternula, blue - Laternula, green - Laternula elliptica.

\section{TABLES}

Table 1. Details of species included in molecular analysis 
Appendix. Critical assessment of the living species of Laternulidae and their synonyms. Type localities are given where known. Note that number of considered valid species and nomenclature differs from Huber (2010) and WoRMS. The classification will evolve as more samples are included in molecular analyses.

\section{LATERNULIDAE}

Genus Exolaternula Habe, 1977 type species: Anatina truncata Lamarck, $1818=L$. spengleri $($ Gmelin, 1791) = L. rostrata $($ Sowerby, 1839). Lithodesma present.

\section{Exolaternula spengleri (Gmelin, 1791)}

Solen spengleri Gmelin 1791: 3228.

Synonyms: Mya anserifera Spengler, 1793: tab 2 fig 8, holotype NHMD 116367 (Gmelin’s name is based on this specimen and figure), Nicobar Islands; Anatina truncata auct. non Lamarck 1818; Anatina rostrata (G.B. Sowerby II 1839); Anatina limicola Reeve, 1863, Japan; Anatina elegans Philippi, 1844, China; Anatina bernicula Lamy, 1934, Tongatabu.

Remarks: Reeve (1860) used the name A. anserifera for a figured specimen from Tasmania now considered to be Laternula tasmanica leading to citations of the former in southern Australia (e.g. Morton 1975)

Distribution: Sri Lanka, Southeast Asia, northern Australia, Philippines, China, southern Japan (Ryukyu Ids).

Exolaternula liautaudi (Mittre, 1844)

Anatina liautaudi Mittre, 1844:16, pl. 104, holotype MNHN-IM- 2000-33234. Manila, Philippines. Image: https://science.mnhn.fr/institution/mnhn/collection/im/item/2000-33234 Synonyms: Laternula limicola auct. non Reeve 1863; L. navicula auct. non Reeve 1863; $L$. marilina auct. non Reeve, 1860; L. gracilis auct. non Reeve, 1860; Anatina kamakurana Pilsbry, 1895, Kamakura, Japan; Anatina pechiliensis Grabau \& King, 1928, Peitaiho, NW China; Laternula nanhaiensis Zhuang \& Cai, 1982, Hepu, Guangxi.

Remarks: There has been much nomenclatural confusion concerning this species; in Japanese, Chinese and Russian literature it is often cited as L. marilina, an Australian species lacking a lithodesma and now synonymised with L. gracilis. Comparison of type specimens shows that $L$. liautaudi, originally described from the Philippines, is the earliest name.

Distribution: Northern Philippines, China, Taiwan, Korea, Japan and eastern Russia (Peter the Great Bay), exotic to northwest America.

Exolaternula erythraea (Morris \& Morris, 1993)

Laternula (Exolaternula) erythraea Morris \& Morris, 1993: 8,19, holotype NHMUK 1992175, Fujairah, United Arab Emirates.

Remarks: L. erythraensis used in error for L. erythraea e.g. Oliver (1995), Fuelner \& Hornby (2006).

Distribution: Arabian Gulf, Gulf of Oman. 
Genus Laternula Röding, 1798, type species: Solen anatinus Linnaeus, 1758. Synonym: Laternulina Habe 1952, type species Anatina japonica Lischke, 1872. Lithodesma absent in adult.

Laternula anatina (Linnaeus, 1758)

Solen anatinus Linnaeus 1758: 673.

Synonyms: Anatina subrostrata Lamarck, 1818; Anatina hispidula Cuvier, 1829;

Anatina amphora Reeve, 1863, Island of Burias, Philippines; Anatina cumingi Reeve, 1863, Amboina; Anatina eximia Reeve, 1863; Anatina flexuosa Reeve 1863, Japan; Anatina labiata Reeve 1863, Ceylon; Anatina siphonata Reeve, 1863, Borneo.

Remarks: no type material for S. anatinus exists. Linnaeus based the name on the figure in Rumphius (1705 pl $45 \mathrm{f} \mathrm{O}$ and subsequent editions) with locality given as ' $\mathrm{O}$. Asiatici'. The figure is poor but has the upturned posterior 'beak' of shells identified as this species. Also figured in Chemnitz (1782: 62 pl. 6, figs 46-48) and according to Lamy (1934) Lamarck (1818) based his name $A$. subrostrata on these figures.

Distribution: East Africa (rare), Red Sea, SE Asia, NW Australia, Philippines, China, Okinawa, southern Japan. Exotic to eastern Mediterranean

Laternula elliptica (King, 1832)

Anatina elliptica King, 1832: 335, holotype NHMUK 197528, South Shetland Islands.

Synonym: Anatina prismatica Sowerby, 1834, South Shetland Islands.

Remarks: usually cited as described by Broderip \& King 1832 but see Coan et al. (2011) for authorship

Distribution: Circum-Antarctica, Kerguelen, South Georgia, South Shetland Islands.

Laternula boschasina (Reeve, 1860)

Anatina boschasina Reeve, 1860, pl. 2, fig. 13, syntypes NHMUK 197513/1-3, Negros

Island, Philippines.

Remarks: Our sequenced species from Darwin is much smaller than the syntypes but has a similar deep sinus, commarginal folds and brown periostracal margin.

Distribution: uncertain but includes southeast Asia, northern Australia.

\section{Laternula bullata (Reeve, 1863)}

Anatina bullata Reeve, 1863, pl. 1 fig 3, syntypes NHMUK 197513/1-3, Sibonga, Zebu, Philippines.

Remarks: The species sequenced from Singapore (sometimes called L. boschasina) is similar to the type with a rounded anterior, tapering posterior and shallow pallial sinus.

Distribution: Southeast Asia. 


\section{Laternula corrugata (Reeve 1863)}

Anatina corrugata Reeve, 1863, pl. 4, fig. 25, NHMUK 197523/1-2, Ticao Island, Philippines.

Remarks: The species sequenced from Shark Bay Western Australia is broadly similar to syntypes of this species but maybe distinct.

Distribution: Philippines, ?Western Australia.

Laternula creccina (Reeve, 1860)

Anatina creccina Reeve, 1860 pl. 2 fig. 12, NHMUK 197512/1-2, Adelaide, Australia.

Synonyms: Anatina vagina Reeve, 1863, Moreton Bay, Australia; Anatina attenuata Reeve, 1863, Sydney, Australia.

Remarks: The Moreton Bay locality for A. vagina is likely erroneous.

Distribution: South-eastern, southern and south-western Australia.

Laternula gracilis (Reeve, 1860)

Anatina gracilis Reeve 1860 pl. 2 fig. 9, NHMUK 19759/1-3 Moreton Bay, Queensland. Synonyms: Anatina marilina Reeve, 1860, Australia; Anatina recta Reeve, 1863, Port Phillip, Victoria, Australia; ?Anatina tasmanica Reeve, 1863,Tasmania.

Remarks: Molecular analysis indicates that specimens identified as three species above are monospecific with $L$. gracilis taking priority. The status of the larger species L. tasmanica is uncertain but shares characters with $L$. gracilis.

Distribution: Eastern Australia from southern Queensland to Victoria and Tasmania.

\section{Laternula impura (Pilsbry 1901)}

Anatina impura Pilsbry, 1901: 208, pl. 19 fig. 9, syntypes ANSP 68536, Sagami, Japan.

Remarks: The status of this species is uncertain.

Distribution: Southern Japan

Laternula japonica Lischke, 1872: 107; figd 1874, pl. 9, figs 7-10, types not located, Tokyo, Japan.

Remarks: This species is often synonymised with $L$. anatina but our molecular results indicate it is genetically distinct. An earlier name may be Anatina blainvillei Reeve, 1863, pl. 3, fig 17, Island of Burias, Philippines.

Distribution: southern Japan.

Laternula laterna (Lamarck, 1818)

Anatina laterna Lamarck 1818: 463. lectotype MNHG 1082/33 selected Beu (2004: 184, figs $18 \mathrm{C}-\mathrm{E})$. 
Synonyms: Anatina cistella Reeve 1863, Moluccas; Anatina constricta, Reeve, 1863, North Australia; A. valenciennesii Reeve, 1863, China.

Remarks: The lectotype is a large specimen with a short posterior beak and differs from the Lamarckian syntype specimens (now paralectotypes) labelled A. laterna in MNHN Paris (Lamy, 1934, pl. 1, fig. 7).

Distribution: northern Australia, Indonesia. Beu (2004) wrongly states, citing Lamprell \& Healy (1998: 214), that the distribution ranges from southern Western Australia to South Australia, Victoria, Tasmania and New South Wales.

Laternula navicula (Reeve, 1863)

Anatina navicula Reeve, 1863 pl. 4 fig 21, NHMUK 197520/1-3, type locality not cited. Synonyms: Anatina barkudaensis Preston 1915 Lake Chilka, India; Anatina barkulensis Preston, 1915, Lake Chilka; Anatina granulosa Preston, 1914, Lake Chilka; Anatina smithi Preston 1905, Sri Lanka.

Distribution: NW Indian Ocean, Arabian Sea, India, Sri Lanka, Andaman Sea.

\section{Laternula sp.}

Remarks: This species collected in Kungkraben Bay, Thailand and called L. corrugata by Prezant et al. (2008) and then changed to L. anatina Prezant et al. (2015) is neither of these taxa. It is broadly similar in shape to L. bullata Reeve, 1860 but molecularly distinct from Singapore specimens that we identify as that species.

The following species are of uncertain status, all are small shells and probably juveniles. Anatina faba Reeve, 1863, Pl 4 fig 22, Brisbane, type not located. Anatina argentea Reeve 1863 pl. 4 fig 29 NHMUK 197526. Anatina prolongata Reeve 1863 pl 4 fig 28. Port Curtis, Queensland, type not located. 


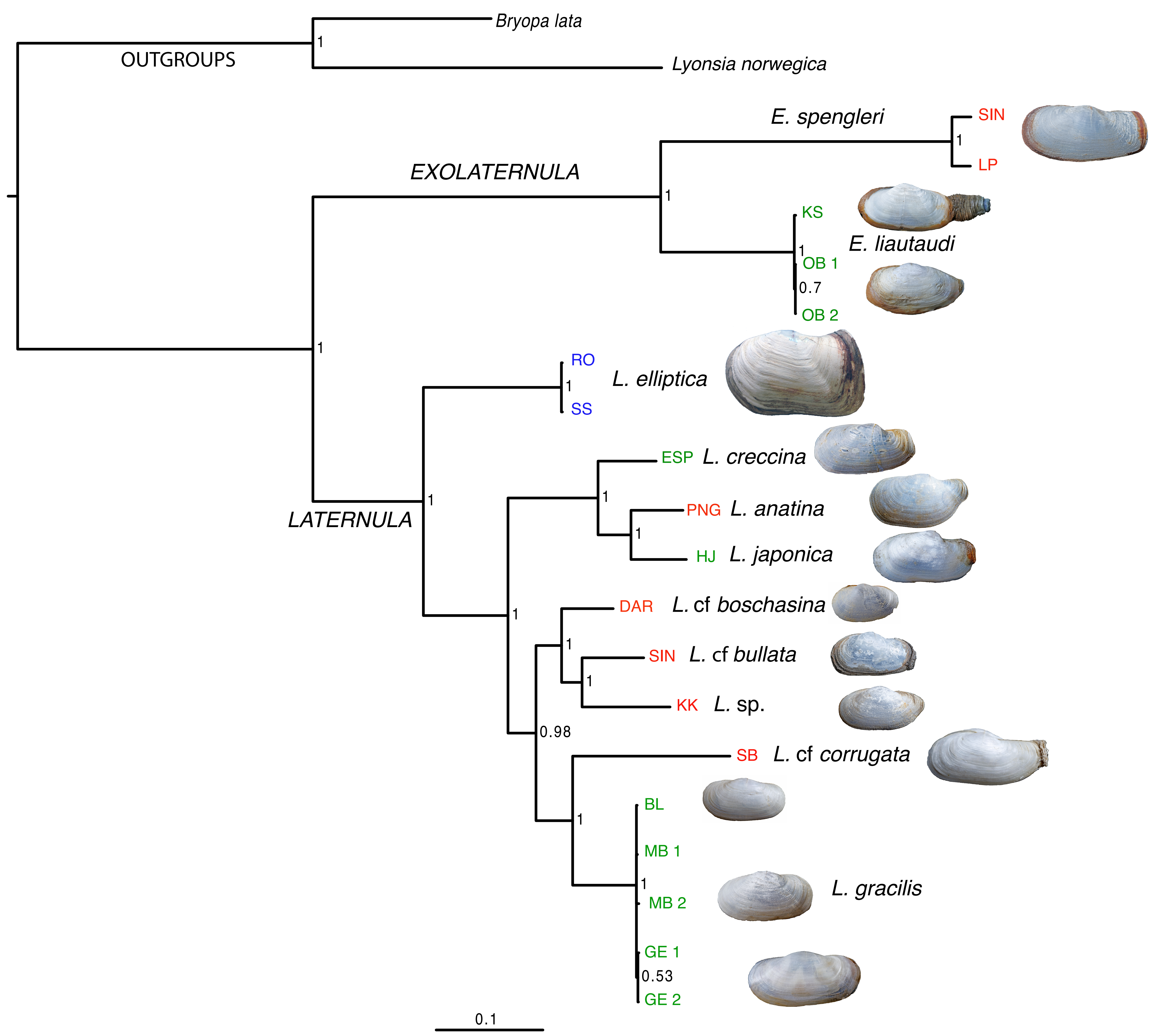




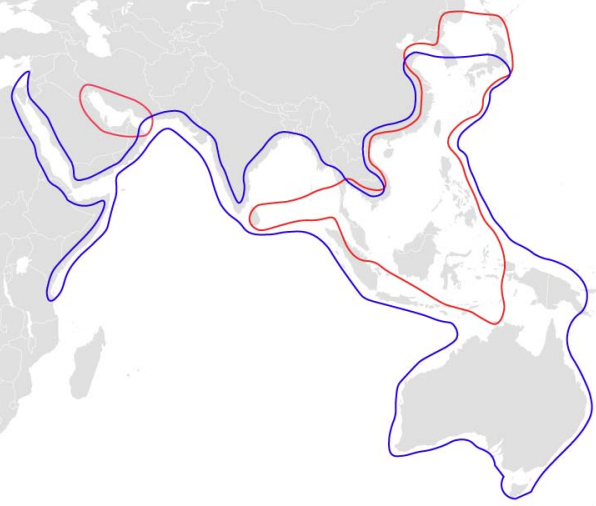


Table 1. Laternulidae species included in the analysis with collection localities, locality codes used in Figure 2, museum registration numbers for vouchers and GenBank accession numbers for the genes sequenced for each taxon. MNHN - Museum national dHistoire Naturelle, Paris; NHMUK - The Natural History Museum, London.

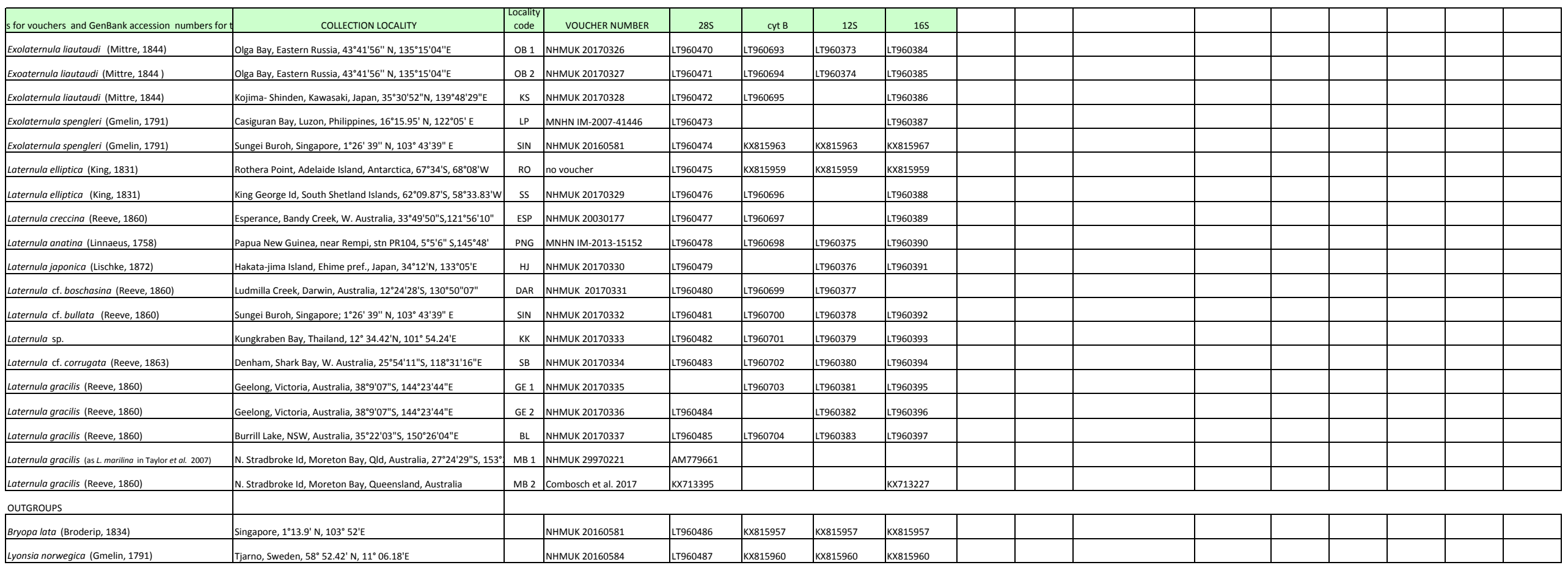

